\title{
THE FUNDAMENTAL RIGHT TO PRIVACY IN BRAZIL AND THE INTERNET PRIVACY RIGHTS IN REGULATING PERSONAL DATA PROTECTION
}

\section{O DIREITO FUNDAMENTAL À PRIVACIDADE NO BRASIL E OS DIREITOS DE PRIVACIDADE NA INTERNET NA REGULAÇÃO DA PROTEÇÃO DE DADOS}

PESSOAIS

\begin{abstract}
VINÍCIUS BORGES FORTES
Doutor em Direito pela UNESA/RJ, linha de pesquisa "Direitos Fundamentais e Novos Direitos, Mestre em Direito pela UCS/RS. Advogado com experiência nas áreas Direito e Novas Tecnologias, Direito do Trabalho e Direito Empresarial. Professor da IMED - Faculdade Meridional nas Escolas de Direito e Sistemas de Informação. Pesquisador do Grupo de Pesquisa em Direito e Desenvolvimento, certificado pela IMED e pelo CNPq. Pesquisador visitante na Universidad de Zaragoza, Espanha. vinibfortes@gmail.com
\end{abstract}

SALETE ORO BofF

Pós-Doutora pela Universidade Federal de Santa Catarina (2008). Doutora em Direito pela Universidade do Vale dos Sinos (2005). Mestre em Direito pela Universidade do Vale dos Sinos (2000). Professora do Programa de Pós-Graduação - Mestrado - em Direito da Faculdade Meridional (IMED). salete.oro.boff@gmail.com

FERNANDO GALINDO AYUDA Chair of Philosophy of Law in the University of Zaragoza. From 1982 Professor Titular of Philosophy of Law. Teaching on Philosophy of Law, Law and Computers and Ethics and legislation for engineers in the University of Zaragoza. From 1986 until today responsible of postgraduate courses of Law and Computers for Spanish, European and Iberoamerican jurists. cfa@unizar.es 
THE FUNDAMENTAL RIGHT TO PRIVACY IN BRAZIL: CONCEPTUAL INCORPORATION OF THE INTERNET PRIVACY RIGHTS IN REGULATING PERSONAL DATA PROTECTION

Vinícius Borges Fortes, SAlete Oro Boff, Fernando Galindo Ayuda

\section{RESUMO}

A Constituição Federal do Brasil, no artigo $5^{\circ}$, inciso $\mathrm{X}$, assegura a inviolabilidade da vida privada, da intimidade e da honra como um direito fundamental. O Marco Civil da Internet instituiu, no Brasil, diversidade de princípios e parâmetros para a regulação da internet no país. A existência da lacuna, no sistema jurídico brasileiro, de norma e infraestrutura, para a efetivação da garantia ao direito à proteção dos dados na internet, já identificada em outros países, associada à ausência de precisão conceitual específica à privacidade na internet, justifica a adoção, nesta pesquisa, do inovador conceito de direitos de privacidade na internet, baseado em Bernal (2014), compostos por quatro direitos-base: navegar com privacidade na internet; monitorar quem monitora; deletar os dados pessoais; proteger a identidade online. Esta pesquisa tem como objetivo geral propor a incorporação conceitual, explícita e expressa, dos direitos de privacidade na internet como um dos pilares para assegurar maior amplitude na eficácia do direito fundamental à privacidade, em especial no processo de criação normativa no Brasil, relacionada à proteção dos dados pessoais na internet. Esta pesquisa utiliza os métodos de procedimento comparativo e histórico, de modo a estabelecer relações e análises dentro da historicidade vinculada aos aspectos da internet e do Direito, da evolução dos direitos fundamentais até o efetivo reconhecimento da privacidade como direito. A pesquisa adota o método de abordagem hipotéticodedutivo, apresentando evidências teóricas, indo dos aspectos gerais aos mais específicos, construindo o aporte teórico que permitiu confirmar e ou refutar as hipóteses preliminarmente formuladas e apresentadas como possibilidades de resolução do problema. O tipo de pesquisa desenvolvido, de natureza qualitativoexploratória, associado à técnica da revisão e análise bibliográfica, contemplando a consulta em referências diversificadas, permitiu a construção dos resultados apresentados na pesquisa, especialmente a proposta de incorporação conceitual.

Palavras-chave: Dados pessoais. Direitos de privacidade na internet. Direitos fundamentais. Internet. Privacidade.

\begin{abstract}
The Brazilian Constitution, Article 5, paragraph X, ensure the inviolability of privacy, intimacy and honour as a fundamental right. The Brazilian Internet Bill of Rights, called 'Marco Civil da Internet', instituted in Brazil diversity of principles and parameters for regulation of internet in the country. The existence of the gap in the Brazilian legal system, around laws and infrastructure for the effective guarantee to the right to data protection on the Internet, as identified in other countries, coupled with the absence of specific conceptual precision to privacy on the internet, justifies the adoption in this research, the innovative concept of 'Internet Privacy Rights', based on Bernal (2014), composed of four rightsbased: a right to roam the internet with privacy; a right to monitor those who monitor us; a right to delete personal data; a right to an online identity. This research has the overall objective to propose a conceptual incorporation, explicit and expressed, of Internet Privacy Rights as one of the pillars to ensure greater extent on the effectiveness of the fundamental right to privacy, particularly in Brazilian process of creation of laws, related to the protection of personal data on the internet. This research uses the methods of comparative and historical procedure in order to establish relationships and analysis within the historicity linked to aspects of the internet and Law, the evolution of fundamental rights to the effective recognition of privacy as a right. The research uses the hypothetical-deductive method of approach, with theoretical evidence, ranging from general aspects to the most specific, building the theoretical framework that allowed and confirm or refute the preliminary hypotheses and presented as the problem solving possibilities. The type of developed research was qualitative and exploratory nature, associated with the technical of review and literature analysis, covering the query varied references, allowed the construction of the results presented in the research, particularly the proposed conceptual incorporation.
\end{abstract}

Keywords: Fundamental rights. Internet. Internet Privacy Rights. Personal data. Privacy.

\section{SUMMARY}

INTRODUCTION; 1 THE USE OF THE INTERNET IN BRAZIL AND THE VULNERABILITY OF RIGHTS AS GROUNDS FOR THE CONCEPTUAL INCORPORATION OF 'INTERNET PRIVACY RIGHTS'; 2 PRIVACY AND PERSONAL DATA PROTECTION ON THE INTERNET IN THE CONCEPT OF 'INTERNET PRIVACY RIGHTS' PROPOSED BY PAUL BERNAL; CONCLUSIONS; REFERENCES. 

REGULATING PERSONAL DATA PROTECTION

\section{INTRODUCTION}

Initially, fits ratify this research does not claim to solve the completeness of gaps existing in the Brazilian normative construction in relation to the theme, including for understanding object that Law, as a science, does not have sufficient regulation and control mechanisms to the neutralization of the legal problems identified on the internet continuously. In this sense, Law is one of the elements that, along with technological development, can contribute to the strengthening of the fundamental right to privacy.

Another highlight with this stage of research lies in the conceptual proposition for the normative construction in Brazil. Clarifies that internet represents the transcendence of geographical boundaries and, because of this, are the situations involving the internet in a transnational context, the general objective of this research focuses on the incorporation of the concept of 'internet privacy rights' in the normative production with regulatory bias of the protection of privacy and the inviolability of the personal data on internet, inside the Brazilian territory.

So, this research intends to establish a theoretical-conceptual link to answer the main question: internet privacy rights must be expressed and explicit, to ensure greater amplitude on efficiency of legal norms that protect the Brazilian straight crucial to privacy in the context of the internet?

Furthermore, surpassed the debate about the need for regulation of the use of the internet in Brazil, with the effectiveness of 'Marco Civil da Internet', the general objective of this research is directly the necessary reflection on how these rules will be applied, and how they will be regulated the specific topics related to privacy and the protection of personal data.

If, on the one hand, 'Marco Civil da Internet' represents a breakthrough in the construction of norms related to the demands of the information society, welcoming appropriate terminology to the internet context, on the other hand, brought the need for regulation of specific topics, such as the section dealing with the protection of privacy and personal data in the network. In addition, it is noteworthy that, in Brazil, also develops the debate on the creation of a personal data protection act, in order to protect the use of personal data in a broad sense, covering even the data obtained, stored and handled from internet applications. Thus, the results of this research connect directly with the imminent and necessary regulation of 
THE FUNDAMENTAL RIGHT TO PRIVACY IN BRAZIL: CONCEPTUAL INCORPORATION OF THE INTERNET PRIVACY RIGHTS IN REGULATING PERSONAL DATA PROTECTION

Vinícius Borges Fortes, SAlete Oro Boff, Fernando Galindo Ayuda

'Marco Civil da Internet', as provided in articles 10, fourth paragraph ${ }^{1}$, and article 11, fourth paragraph $^{2}$ as well as will contribute to the discussion of the subject of protection of personal data in the context of developing Brazilian general law regulations.

Thus, this research provides recent data about the context of the use of the internet in Brazil, in order to elucidate the vulnerabilities of rights in that space, thus demonstrating the need for the establishment of latent specific regulatory framework by introducing the concept of 'internet privacy rights', and analysing the prospects of the theme of the protection of privacy and personal data in Brazil, especially from the normative and conceptual review carried out in the previous chapters, showing the merger proposal for a conceptual construction of norms related to the theme, in order to answer the problem of research and fulfil the general objective.

\section{THE USE OF THE INTERNET IN BRAZIL AND THE VULNERABILITY OF RIGHTS AS GROUNDS FOR THE CONCEPTUAL INCORPORATION OF 'INTERNET PRIVACY RIGHTS'}

To the future or to the past, to a time when thought is free, when men are different from one another and do not live alone - to a time when truth exists and what is done cannot be undone: From the age of uniformity, from the age of solitude, from the age of Big Brother, from the age of doublethink - greetings! (George Orwell, '1984') ${ }^{3}$.

\footnotetext{
1 Art. 10. The custody and the availability of connection records and access to internet applications contemplated in this law, as well as personal data and private communications content must meet the preservation of intimacy, private life, honour and image of the parties directly or indirectly involved. [...] $\S 4$ the measures and procedures for security and confidentiality should be informed by the person responsible for service provision clearly and meet the standards set in regulation, respected their right to confidentiality as corporate secrets. BRASIL. Lei n..$^{\circ}$ 12.965, de 23 de abril de 2014. Disponível em: <http://www.planalto.gov.br/ccivil_03/_ato2011-2014/2014/lei/l12965.htm>. Acesso em: 21 abr. 2015.

2 Art. 11. In any operation of collection, storage, custody and treatment of personal data records or communications connection and providers of internet applications in which at least one of these acts from occurring in the national territory, shall be compulsorily complied with Brazilian legislation and the rights to privacy, to protection of personal data and confidentiality of private communications and records.

[...] § 4 Decree will regulate the procedure for verification of infractions of the provisions in this article. BRASIL. Lei ${ }^{\circ}{ }^{\circ} 12.965$, de 23 de abril de 2014.

${ }^{3}$ ORWELL, G. 1984. New York: Houghton Mifflin Harcourt, 1983.
} 
THE FUNDAMENTAL RIGHT TO PRIVACY IN BRAZIL: CONCEPTUAL INCORPORATION OF THE INTERNET PRIVACY RIGHTS IN REGULATING PERSONAL DATA PROTECTION

Vinícius Borges Fortes, SALETE Oro Boff, Fernando Galindo AyUda

Although already elucidated in the research is again one of the elements that motivated the filing of the Bill, which aimed to establish the Brazilian Internet Bill of Rights, popularly called 'Marco Civil da Internet'. National research for sample of Domiciles, carried out in the year 2009 by IBGE, signalled the existence of 68 million internet users in Brazil, with growth rate of approximately one million every three months ${ }^{4}$.

The data presented here could be interpreted as a positive sign of opportunities, but also observed as possibilities of risks and vulnerabilities arising from the absence of any express recognition of fundamental rights, in the context of the internet. Furthermore, the explanatory memorandum of this Bill indicated that the absence of specific standards conferred to Brazil with the risk of disjointed proposals specialized regulatory approval, which would generate disagreement and would harm the harmonic treatment of matter. It also could represent sensitive judicial losses, until the jurisprudence suited to the realities of the information society, as well as misunderstandings or omissions in public policies and, especially, the risk of violation of rights of progressive internet users by practices and freely contracts signed with internet service providers, in a broad sense ${ }^{5}$.

In this context, it is relevant to consider the growth of internet usage in Brazilian household environments. The CETIC.br (Regional Centre of studies for the development of the information society), held within the framework of the CGI.br (Brazilian Internet Management Committee), develops, since 2005, the research entitled "ICT Households", with the purpose of "[...] measure the possession, the use and usage habits of computer, internet and mobile devices of the Brazilian population from 10 years old [... $]^{\prime \prime 6}$.

The recent survey by the CETIC.br, referring to the year 2013 and presented in 2014, shows results that are divided into four categories: (i) the home access to technology, addressing the presence of information technology equipment and communication and internet connection in Brazilian homes; (ii) the use of the internet; (iii) the activities carried out on the internet;

\footnotetext{
${ }^{4}$ BRASIL. Exposição de motivos ao projeto de lei $n .^{\circ} 2.126 / 2011$. Disponível em:

<http://www.planalto.gov.br/ccivil_03/Projetos/ExpMotiv/EMI/2011/86-MJ MP MCT MC.htm>. Acesso em: 24 dez. 2012.

${ }^{5}$ BRASIL. Exposição de motivos ao projeto de lei n. ${ }^{\circ} 2.126 / 2011$.

${ }^{6}$ BARBOSA, Alexandre F. Pesquisa sobre o uso das Tecnologias de Informação e Comunicação no Brasil TIC Domicílios e Empresas 2013. São Paulo: Comitê Gestor da Internet no Brasil, 2014. Disponível em: <http://www.cetic.br/publicacao/pesquisa-sobre-o-uso-das-tecnologias-de-informacao-e-comunicacaono-brasil-tic-domicilios-e-empresas-2013/>. Acesso em: 31 mar. 2015. p. 162.
} 
THE FUNDAMENTAL RIGHT TO PRIVACY IN BRAZIL: CONCEPTUAL INCORPORATION OF THE INTERNET PRIVACY RIGHTS IN REGULATING PERSONAL DATA PROTECTION

Vinícius Borges Fortes, SALETE Oro Boff, Fernando Galindo AyUda

and (iv) indicators of cell phone ownership and use, including the use of the internet by means of this equipment ${ }^{7}$.

In this Edition, the survey exposes the growing presence of computers in households in Brazil, showing that $49 \%$ of households possessed computer and $43 \%$ had internet access. However, there is a disparity between social classes, with regard to home access to the internet. According to the study, $98 \%$ of the population of the class A have access to the network; in class $\mathrm{B}$, the proportion drops to $80 \%$; in class C, to $39 \%$; in classes $\mathrm{D}$ and e, to $8 \%$. So positive, the research shows an increase in the proportion of internet users, being the first time she goes beyond the half of the population. It was also noted the growth in the number of internet users by cell phone, that hit in 2013 , the proportion of $31 \%$ of the population ${ }^{8}$.

Of course, the significant increase in the presence of computers and of internet access in households makes the potential increase in the number of individuals subjected to transgressions of internet rights, especially the fundamental right to privacy through the violation of personal data. In addition to the risks related to data mining by private companies, specialising in collecting private data for commercial purposes, users of mobile telephony and internet services were (and possibly in the future are and will still be) subject to mass surveillance practices by the U.S. Government, by the programs of the NSA ${ }^{9}$.

In a complementary manner to global institutional reactions, from the Resolution $\mathrm{n}^{\circ}$ 69/166, of December 18th, 2014, issued by the United Nations General Assembly, in particular after proposals put forward by Brazil in conjunction with Germany, was approved in March of the year 2015, the establishment of a Special Rapporteur of the Human Rights Council for monitoring of issues related to violations of the human right to privacy globally ${ }^{10}$.

Stresses the mentioned UN General Assembly resolution recognising the discussion and analysis of matters linked to the promotion and protection of the right to privacy and other human rights in the digital age, as well in the international human rights, as well as assessing the impact of the acts of mass surveillance. The resolution states that the internet is a global

\footnotetext{
${ }^{7}$ BARBOSA, Alexandre F. Pesquisa sobre o uso das Tecnologias de Informação e Comunicação no Brasil TIC Domicílios e Empresas 2013.

${ }^{8}$ BARBOSA, Alexandre F. Pesquisa sobre o uso das Tecnologias de Informação e Comunicação no Brasil TIC Domicílios e Empresas 2013.

${ }^{9}$ GREENWALD, Glenn; KAZ, Roberto; CASADO, José. EUA espionaram milhões de e-mails e ligações de brasileiros - Jornal O Globo. O Globo, Rio de Janeiro, jul. 2013. Disponível em:

<http://oglobo.globo.com/mundo/eua-espionaram-milhoes-de-mails-ligacoes-de-brasileiros8940934\#ixzz2q7eRkKbW>. Acesso em: 3 jan. 2015.

${ }^{10}$ ASSEMBLEIA GERAL DAS NAÇÕES UNIDAS Resolution adopted by the General Assembly on 18 December 2014 - 69/166. The right to privacy in the digital age. . New York: [s.n.], 2014.
} 
THE FUNDAMENTAL RIGHT TO PRIVACY IN BRAZIL: CONCEPTUAL INCORPORATION OF THE INTERNET PRIVACY RIGHTS IN REGULATING PERSONAL DATA PROTECTION

Vinícius Borges Fortes, SAlete Oro Boff, Fernando Galindo Ayuda

nature and open technology, which, associated with the accelerated pace of development of information and communication technologies, broadens considerably the ability of Governments, business organizations and individuals conducting surveillance, interception and collection of data, having as direct consequence the occurrence of human rights abuses, in particular the right to privacy, protected by article 12 of the Universal Declaration of human rights and by article 17 of the International Covenant on Civil and Political Rights ${ }^{11}$.

The resolution considers that, given the wide possibility of use of metadata as a way of revealing personal information, such as individual behaviour, social relations, private preferences and internet user identity, treat privacy protection as a human right is essential. Another point of relevance of the resolution concerning the international community's concern with the negative impact generated by public denunciations of acts of surveillance and/or communications interception, including extraterritorial, as well as the collection of personal data on a large scale, which reinforces the finding of contempt of human right to privacy protection and the guarantee of inviolability of personal data ${ }^{12}$.

There is no doubt that the problems involving the legal guardianship of the fundamental right to privacy, in order to ensure the inviolability of personal data on the internet, transcend geographical borders. In particular, Varella ${ }^{13}$ explains that

The internet, specifically, and the technological revolution, so wide, enable a coupling between different times and spaces in the field of law and politics. Each State or community has its own times in this process. The relationship between them is not of greater or lesser development, because walk their own paths. Occurs a process of mutual influence, or mutual irritation, as some authors prefer, in logic of expansion of contract between social systems. Economy, politics, science and law have communicative discourses own that are not antagonistic, but complement each other. With the internet, it is extended the influences between other spheres of construction of social systems, national and foreign, typically before interacting more strongly with national, foreign, and international ideas, from direct and immediate contact of actors involved internally and externally on the internet

\footnotetext{
${ }^{11}$ CONSELHO DE DIREITOS HUMANOS DAS NAÇÕES UNIDAS, 2015. Criação da Relatoria Especial sobre "O Direito à Privacidade na Era Digital". Disponível em:

<http:/ / www.itamaraty.gov.br/index.php?option=com_content\&view=article\&id=8460:criacao-darelatoria-especial-sobre-o-direito-a-privacidade-na-era-digital\&catid=42\&ltemid=280\&lang=pt-BR>. Acesso em: 31 mar. 2015.

12 CONSELHO DE DIREITOS HUMANOS DAS NAÇÕES UNIDAS, 2015. Criação da Relatoria Especial sobre "O Direito à Privacidade na Era Digital".

${ }^{13}$ VARELLA, Marcelo Dias. Internacionalização do direito: direito internacional, globalização e complexidade. Brasilia: UniCEUB, 2013. p. 41-42.
} 


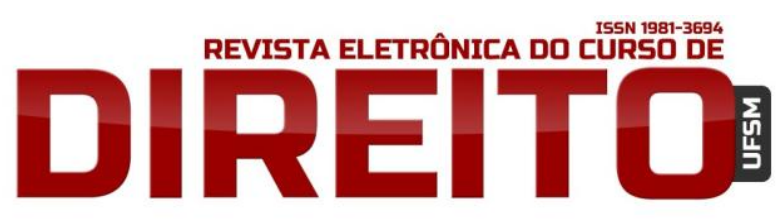

THE FUNDAMENTAL RIGHT TO PRIVACY IN BRAZIL: CONCEPTUAL INCORPORATION OF THE INTERNET PRIVACY RIGHTS IN REGULATING PERSONAL DATA PROTECTION

Vinícius Borges Fortes, SAlete Oro Boff, Fernando Galindo Ayuda

Thus, the issue involving the NSA and data collection and information of individuals and Governments inevitably enters the theme of sovereignty of States. However, renewed the observation that this research does not object the topic linked to the theory of the State, since it focuses on conceptual merger proposal for building Brazilian legislation, aimed at protecting the privacy and personal data on the internet. Nevertheless, when dealing with the topic of mass surveillance, this research suggests a conceptual merger proposal as one of the institutional responses to partial solution, and restricted to the national level, the surveillance carried out episodes by Governments, companies and individuals, converging on the handling of the subject of privacy and protection of personal information and not for the conceptual contradiction of the sovereignty of States vis-à-vis the transnational nature of the network.

Thus, the conceptual incorporation of 'internet privacy rights' may contribute to the standardization of the theme of privacy and personal data protection on the internet, especially vis-à-vis the impending regulation of 'Marco Civil da Internet' and the advance in the discussion of the draft bill of rights on protection of personal data in Brazil.

\section{PRIVACY AND PERSONAL DATA PROTECTION ON THE INTERNET IN THE CONCEPT OF 'INTERNET PRIVACY RIGHTS' PROPOSED BY PAUL BERNAL}

To initiate this section it is important to clarify that this research is linked to the category of rights built by Bernal ${ }^{14}$ which consist of not only the recognition of the right to privacy on the internet, but in the definition of a set of 'internet privacy rights'.

The discussion around the issue of privacy is not new, and the general concern of society with the matters related to privacy protection is significant and growing. Both recent announcements of companies of information and communications technology, such as Google and Facebook, are always referred to issues related to the maintenance, improvement or the commitment of the tools developed by them concerning user privacy. Authorities also have taken seriously the issue of privacy. In the United States, Google and Facebook will be audited for 20 years and Twitter, for 10 years, by FTC - Federal Trade Commission, the agency

\footnotetext{
${ }^{14}$ BERNAL, P. Internet Privacy Rights: Rights to Protect Autonomy. Cambridge (UK): Cambridge University Press, 2014.
} 
THE FUNDAMENTAL RIGHT TO PRIVACY IN BRAZIL: CONCEPTUAL INCORPORATION OF THE INTERNET PRIVACY RIGHTS IN REGULATING PERSONAL DATA PROTECTION

Vinícius Borges Fortes, SALETE Oro Boff, Fernando Galindo AyUda

responsible for monitoring and protection of consumer rights, so that, during this period, companies will promote a series of adjustments related to the privacy of users of the services provided by them on the internet ${ }^{15}$.

It is observed that one of the main reasons why there is a great deal of concern with the theme of privacy on the part of all those involved in the use of the internet (i.e. by a multistakeholder users ${ }^{16}$ ), is the fact that all care about privacy, as evidenced the mentioned research, requested jointly, in 2011, by the General Directorate of Justice, information society, Media and Common Centre for research in the European Union.

The relationship between the legal protection of privacy and personal data and the network society is absolutely close of each one, because internet offers wide range of opportunities for collection, analysis, use and storage of personal data, which are reversed for multiple purposes. At that point, the model suggested by Web symbiotic has strong influence on the generation of these opportunities for collection, analysis, use and storage of personal data and information.

It becomes incredibly difficult, nowadays, separate data and information online and offline. Since the internet has become more integrated with the 'real world', data online and offline mingle easily. A typical example that some data generated in the 'real world' are used in cyberspace can be observed in the case of the British Tesco supermarket network. From the Tesco Clubcard, a loyalty program created by the network, it is possible to collect data from purchases made in the 'real world' that are mapped and crossed with purchases made on the internet ${ }^{17}$.

In this way, the network began to store details of every consumer in the United Kingdom, from the domicile to a range of demographic characteristics, socioeconomic and lifestyle. By means of an artificial intelligence system called Zodiac, was possible to create

\footnotetext{
${ }^{15}$ BERNAL, P. Internet Privacy Rights: Rights to Protect Autonomy.

16 "The multistakeholder model, or from multiple stakeholders, allows the participation and consideration of all stakeholders who matter in a system - whether Governments, sectors of the private sector or civil society, including academic and technical sectors - in egalitarian basis and through an inclusive process. This is precisely the model used by the IGF [Internet Governance Forum], organ created officially by the United Nations Secretary-General in July 2006 and that, since then, meets annually, always in OctoberNovember. It is also the form of Administration used by ICANN. The entity of international governance of the internet is composed of different stakeholders throughout the world and practice a policy of development multiconsensual to administer the network. This model was developed on the basis of global collaborations received by White Paper which detailed the policy sponsored by the United States for the management of internet names and addresses-and which led to the creation of ICANN in 1998 " (BRASIL, 2013a).

${ }^{17}$ BERNAL, P. Internet Privacy Rights: Rights to Protect Autonomy.
} 
THE FUNDAMENTAL RIGHT TO PRIVACY IN BRAZIL: CONCEPTUAL INCORPORATION OF THE INTERNET PRIVACY RIGHTS IN REGULATING PERSONAL DATA PROTECTION

Vinícius Borges Fortes, SAlete Oro Boff, Fernando Galindo Ayuda

intelligent profiles and segmentation of customer data. So the client profile can be classified as your enthusiasm for promotions, its fidelity to brands and other buying habits ${ }^{18}$.

On top of that, the company went on to sell access to the database named Crucible to companies from different segments, such as Sky (paid TV), Gillette (razors and cosmetics) and Orange (television and internet services provider). Together, the Crucible and the Zodiac can generate a map of how an individual often thinks, works and stores. Furthermore, the map is able to classify consumers in 10 categories: (i) wealth; (ii) promotions; (iii) trips; (iv) charity; (v) 'green' consumption; (vi) financial difficulties; (vii) credit; (viii) lifestyle; (ix) habits; (x) adventures $^{19}$.

As evidenced, internet has introduced new levels of vulnerability to new forms of collection of the personal data, which were collected, stolen or obtained by other means, appropriate or inappropriately: they now can get lost in the world for many different purposes. It is therefore essential to approach the study of fundamental rights to transgressions, increasingly frequent, these internet rights, especially in relation to the protection of privacy and personal data.

In that sense, this research supports the need for the recognition of basic rights for the effective legal protection of privacy and personal data on the internet, in particular the incorporation of the concept of 'internet privacy rights' as one of the pillars for the regulation of personal data protection in Brazil, thus seeking greater effectiveness of the fundamental right to privacy. However, so purposeful, it is relevant to note that the basic rights identified by the doctrine, for which contextual adjustments are performed at Brazilian law properly.

In that order, are presented four basic rights which transcend the meaning of legal rights, since they represent real desires understood and considered by the people as your right, especially from the protection of the autonomy of each individual. In that coach, are considered the four basic rights that constitute the internet privacy rights: (i) the right to roam the internet with privacy; (ii) the right to monitor those who monitor us; (iii) the right to delete personal data; (iv) the right to an identity online ${ }^{20}$.

\footnotetext{
${ }^{18}$ LEITH, Philip. Privacy as slogan. In: SAARENPÄÄ, AHTI (Org.). . Legal privacy. Zaragoza: Prensas de la Universidad de Zaragoza, 2009. p. 93-112.

${ }^{19}$ Tesco stocks up on inside knowledge of shoppers' lives. The Guardian, London, 20 set. 2005. Disponível em: <http://www.theguardian.com/business/2005/sep/20/freedomofinformation. supermarkets>. Acesso em: 8 fev. 2015.

${ }^{20}$ BERNAL, P. Internet Privacy Rights: Rights to Protect Autonomy.
} 
THE FUNDAMENTAL RIGHT TO PRIVACY IN BRAZIL: CONCEPTUAL INCORPORATION OF THE INTERNET PRIVACY RIGHTS IN REGULATING PERSONAL DATA PROTECTION

Vinícius Borges Fortes, SAlete Oro Boff, Fernando Galindo Ayuda

The first right, binds to the possibility of navigation for Web pages-whether in search of information, whether in search of data, whether in the purchase of products in e-commerce platforms - with the reasonable expectation of doing so with privacy, not as an absolute standard, but as a general rule ${ }^{21}$.

Of course, suggest that means putting in check all business models that fully used the internet to interact with users (web-based ${ }^{22}$ services), and that are absolutely justified in Web symbiotic. Most search engines, like Google, have been developed to work in symbiosis with the users, i.e., in Exchange for free services, the user provides personal information and consent, when starting the use of the services, that personal information are collected during internet navigation, stored and used for various purposes, including commercial.

In addition, there's the argumentative component, used often by the companies of information and communications technology, which coming up strongly in the recognition of that right. According to these companies, the provision of data and personal information from internet browsing are useful for various purposes and, mainly, for optimizing and improving the user experience on the Web, making the internet more interesting as advocating Phorm, a company that use deep packet inspection technologies to collect personal data on internet.

However, the right to roam the internet with privacy should extend beyond the search engines, reaching also any other navigation service, such as access providers (originally named ISPs - Internet Service Providers) ${ }^{23}$. The formal recognition of the right to roam the internet with privacy could generate conflict inevitable with governmental practices, especially with the surveillance $^{24}$ and data retention. However, this inevitable tension is essential, so that the argument of national security exceed, automatically and always, the fundamentals of privacy protection.

Soon, the recognition of the right to roam the internet with privacy does not mean a 'carte blanche' to operate without balance, without proper accountability or without consequences for each act committed on the network ${ }^{25}$, which connects with the second basic right that makes up the core of the 'internet privacy rights'.

\footnotetext{
${ }^{21}$ BERNAL, P. Internet Privacy Rights: Rights to Protect Autonomy.

${ }^{22}$ Corresponds to an internet application, namely, a computer system that depends on access to the internet to its full use.

${ }^{23}$ BERNAL, P. Internet Privacy Rights: Rights to Protect Autonomy.

${ }^{24}$ MORAIS, José Luis Bolzan; NETO, Elias Jacob. A insuficiencia do Marco Civil da Internet na protecão das comunicac,ões privadas armazenadas e do fluxo de dados a partir do paradigma da surveillance. In: LEITE, G; LEMOS, R (Org.). . Marco Civil da Internet. São Paulo: Atlas, 2014. p. 417-439.

${ }^{25}$ BERNAL, P. Internet Privacy Rights: Rights to Protect Autonomy.
} 
THE FUNDAMENTAL RIGHT TO PRIVACY IN BRAZIL: CONCEPTUAL INCORPORATION OF THE INTERNET PRIVACY RIGHTS IN REGULATING PERSONAL DATA PROTECTION

Vinícius Borges Fortes, SAlete Oro Boff, Fernando Galindo Ayuda

The second right, complementary to the previous one, concerns the right to know who monitor, what monitor, when monitor and for which purposes does it. There are circumstances linked to the right to roam the internet with privacy, there are situations in which individuals want to be monitored, beneficial for some reason. From the perspective of privacy protection, data collection and monitoring constants are absolutely negative acts. However, under the prism of the Web symbiotic are absolutely beneficial acts to the usability of the network by the user ${ }^{26}$.

Given this conceptual and antagonistic impasse, users have a right to know when, by whom, for what, and what is being precisely tracked, logged, stored and analysed. Monitor the monitors means more than simple knowledge of what data are being collected. It is about the individual knowing if they are being monitored, possibly even without retention of data and information, and for what purpose such an act is intended. This is to establish a principle of collaborative consent, with the consent considered immediate mode, interactive, dynamic, and binary, within the processes of interaction on the internet ${ }^{27}$.

The third right, to delete the personal data, deserves here important differentiations. Some authors brought to light the expression 'right to be let alone', employed by Cooley and reproduced by Warren e Brandeis (1890), to configure the right to be left alone, giving the beginning of recognition of the right to privacy $^{28}$.

However, such expression is often understood as a synonym of a right already recognised, including in Brazilian law, namely the right to be forgotten. However, this right, as it addresses this topic, is suited to the concept used by Bernal ${ }^{29}$, i.e. to the so-called 'right to be forgotten', since it goes beyond the mere protection of private life, giving the possibility of a delete user data and personal information from the internet.

An example of this conceptual confusion can be observed in Júnior e $\mathrm{Neto}^{30}$, explaining that the right to be forgotten is named, in American law, 'the right to be let alone'. It means to guarantee that the data about an individual may only be kept to enable the identification of a

\footnotetext{
${ }^{26}$ BERNAL, P. Internet Privacy Rights: Rights to Protect Autonomy.

27 BERNAL, P. Internet Privacy Rights: Rights to Protect Autonomy.

${ }^{28}$ BERNAL, P. Internet Privacy Rights: Rights to Protect Autonomy.

29 BERNAL, P. Internet Privacy Rights: Rights to Protect Autonomy.

30 JÚNIOR, Antonio Rulli; NETO, Antonio Rulli. Direito ao Esquecimento e o Superinformacionismo Apontamentos no Direito Brasileiro dentro do Contexto de Sociedade da Informação. Revista do Instituto do Direito Brasileiro, v. 1, n. 2012, p. 419-434, 2012. Disponível em: <http://www.idbfdul.com/uploaded/files/RIDB_001_0419_0434.pdf>.
} 
THE FUNDAMENTAL RIGHT TO PRIVACY IN BRAZIL: CONCEPTUAL INCORPORATION OF THE INTERNET PRIVACY RIGHTS IN REGULATING PERSONAL DATA PROTECTION

Vinícius Borges Fortes, SALETE Oro Boff, Fernando Galindo AyUda

subject connected to the events and only as long as necessary to achieve their purposes. The right here discussed, corresponds to the 'right to be forgotten', well in depth.

In Conference at New York University, the Google's CEO, Eric Schmidt mentioned that one of the great challenges of the future of the internet is creating a 'delete' button, so that people have the opportunity to delete publications related to acts carried out in the past, for which do not wish to display more search results or indexed pages on the Web ${ }^{31}$.

The discussion about the possibility of having ' $a$ ' ${ }^{32}$ right to be forgotten is ancient. She comes from the conflict of individuals with the press and with the media, unauthorized publications or whose contents would not match the entirety of facts and truth. A few years ago, the concern resided in the withdrawal from circulation of magazines and newspapers, newsstands shelves so that the information allegedly mistaken not to circulate among readers, avoiding thus the outbreak of alleged untruths. In this context, the question linked more to the concept of 'right to be let alone'.

However, in the 'internet age' and to the consolidation of cyberspace, it is shown the inevitable debate about the possibility of introducing a 'delete button' to delete the logs of Web information is not desired by any of the subjects involved.

The question of the application of ' $a$ ' right to be forgotten was subjected to the analysis of the Court of Justice of the European Union, sued by the Spanish judiciary. From a lawsuit brought by the Spanish lawyer Mario Costeja versus Google, with the goal of deleting an article of the journal La Vanguardia, dating from 1998, which made reference to an auction of real estate and a garnishment for debts to the social security system. In that circumstance, the General Advocate of the European Union expressed his opinion, by failure to apply the right to be forgotten in cases of this nature.

Thus, according to the General Advocate of the European Union, search engines, in case Google, should not be held responsible for the handling of pages indexed, so it can be held accountable for searches and therefore cannot be obliged to exclude certain search results. Furthermore, the determination of the judiciary-driven search engine for blocking sites would

\footnotetext{
${ }^{31}$ TIBKEN, Shara. Google' s Schmidt: The Internet needs a delete button. Disponível em: <http://www.cnet.com/news/googles-schmidt-the-internet-needs-a-delete-button/>. Acesso em: 23 ago. 2013.

32 In this section, and within the Brazilian context, this study did not adopt the name of 'the' right to be forgotten, because the perception of the researcher, it is ' $a$ ' right to be forgotten, since it still represents an interpretive proposal on the right to privacy and the principle of dignity of the human person, from the weighting and of statements, without the existence of prior standard to authorize your application within the context under consideration.
} 
THE FUNDAMENTAL RIGHT TO PRIVACY IN BRAZIL: CONCEPTUAL INCORPORATION OF THE INTERNET PRIVACY RIGHTS IN REGULATING PERSONAL DATA PROTECTION

Vinícius Borges Fortes, SAlete Oro Boff, Fernando Galindo Ayuda

mean the judicial authorization of censorship, behold, would interfere with the freedom of speech in cyberspace. Still, the Directive 95/46/EC, which regulates the processing of personal data in the European Union, allows the exclusion of bungled information, incorrect or incomplete. However, for the real information, there is no need to talk in 'to be forgotten'33.

Due to this type of demand, Google has set up what he called 'Advisory Council to Google on the Right to be Forgotten' formed by experts in the subject. After a job schedule that included meetings and hearings with interested parties, the Advisory Council issued, on February 6th, 2015, a 44-page report, with recommendations on what the company of information and communications technology can do in cases of requisition of right to be forgotten ${ }^{34}$.

The report proposes the categorization of users of Google's services, for the purposes of analysis of applications that claim the right to be forgotten. According to the report, users can be grouped into three different categories, according to their social relevance, as shown in the table below:

Group categories

Treatment of the requisition of the right to be forgotten

(i) Individuals who play a role in public life, requests for such individuals are less likely to justify undoubtedly, such as politicians, CEOs, deleting data, since the general public have a primary celebrities, religious leaders, sports 'stars', interest in the search for information about them, artists):

(ii) Individuals with no perceptible role in requests for deletion of data for these individuals are public life:

(iii) Individuals with a limited or specific role in the context of public life, such as school principals, some categories of public officials, or individuals who can play a public role, within a community, because of their profession: through a research based on their names.

more likely to justify the exclusion.

requests for deletion of data from such individuals are neither more nor less likely to justify, depend on the content of information, specifically to consider for purposes of decision to exclude.

Source: Adapted from Google ${ }^{35}$.

\footnotetext{
33 JÄÄSKINEN, Niilo. Conclusões do advogado-geral apresentadas em 25 de junho de 2013 - Processo C131/12 - Google Spain SL, Google Inc. vs. Agencia Española de Protección de Datos, Mario Costeja González. . [S.l: s.n.], 2013.

${ }^{34}$ GOOGLE. Report of The Advisory Council to Google on the Right to be Forgotten Members of the Council. San Francisco, EUA: [s.n.], 2015. Disponível em:

<https://drive.google.com/file/d/OB1UgZshetMd4cEI3SjlvVOhNbDA/view>.

${ }^{35}$ GOOGLE. Report of The Advisory Council to Google on the Right to be Forgotten Members of the Council.
} 
THE FUNDAMENTAL RIGHT TO PRIVACY IN BRAZIL: CONCEPTUAL INCORPORATION OF THE INTERNET PRIVACY RIGHTS IN REGULATING PERSONAL DATA PROTECTION

Vinícius Borges Fortes, SAlete Oro Boff, Fernando Galindo Ayuda

At this point, it is important to reflect on the limits that a business organization such as Google, which owns a significant part of the information organized within the internet, defines group categories for which that should be applicable, and under what circumstances and conditions, the right to delete personal data will occur. The mere possibility of determining these categories already points to a fragility in the legal norms that protect implicitly the right to be forgotten.

On the freedom of establishment of limits and criteria themselves, without any intervention of the right on these, the experts of Google has categorized, depending on the nature of the information, the types of information that make the interest in privacy protection larger or smaller. On the categorization of information 'type' and 'nature', associated with the category of individuals potentially interested in your own privacy, according to criteria adopted by Google, it is reasonable to question: What the public and/or private dimension of the internet these days? Should the internet, or a significant part of it, be considered a 'public space' and, if it should, what would be the implications of that?

If the answer is Yes, the implications are considerable, not only for the rights of individuals and the way they browse the Web or use services web-based (i.e. that rely on internet to be fully provided and accessed), but also to the obligations of those who provide or host sites or offer these services web-based ${ }^{36}$.

Measure how public internet is, is absolutely quite complex. Answer this questioning is not something simple, especially from the point of view of normative production classical, and pervades necessarily by questioning about what cyberspace and the internet is. Would be a simple collection of private spaces, connected, each with its owner, its rules and its own way to manage them $?^{37}$

Most of the internet is, in practice, private property and develops as such. Should the internet be considered something effectively private, with users having to follow any rules defined by the owner, particularly in terms of privacy? Is the internet a public space administered by public rules and standards, with expectations that users should have certain rights, and that these rights should be respected regardless of the way you roam the Web? ${ }^{38}$

The direct implication of the statement to be the internet a 'public thing', especially now, an intrinsic part of contemporary life, meets the effective possibility for users to claim

\footnotetext{
${ }^{36}$ BERNAL, P. Internet Privacy Rights: Rights to Protect Autonomy.

${ }^{37}$ BERNAL, P. Internet Privacy Rights: Rights to Protect Autonomy.

${ }^{38}$ BERNAL, P. Internet Privacy Rights: Rights to Protect Autonomy.
} 
THE FUNDAMENTAL RIGHT TO PRIVACY IN BRAZIL: CONCEPTUAL INCORPORATION OF THE INTERNET PRIVACY RIGHTS IN REGULATING PERSONAL DATA PROTECTION

Vinícius Borges Fortes, SAlete Oro Boff, Fernando Galindo Ayuda

their rights and to see them respected, worth it to trading standards, intellectual property, defamation, distribution of pornographic content, etc. ${ }^{39}$. There are, however, jurisdictional issues, complications and principles that need to be unveiled. Despite the Declaration of independence of cyberspace, proclaimed by Barlow ${ }^{40}$, the laws have been applied in 'online life', with varying degrees of success and shapes quite diverse.

One can consider the internet as a significant and extensive public space, over which rights are fully applicable, in direct consequence, just like any other public space. If people have the need to use the internet and, today, already have the recognition of the fundamental right of access to it, it is clear that there should be adequate means of protection and rights to its use ${ }^{41}$.

It is relevant to reflect on which parts of the internet should be considered public or private and, consequently, of which species of rights (and in particular, what degree of privacy) someone that uses each of these parties may reasonably make fun. The most appropriate response to this reflection, and that can serve as a standard, assumes that all the spaces of the internet should be considered public spaces, except if there is compelling reason to the contrary ${ }^{42}$.

As a result of categorization presented by experts from Google, were listed the types of information, as well as the nature of this, for the purposes of observation under the bias in the public interest. However, the types of information presented may collide with what comprises normatively as 'sensitive personal data', that can reveal personal information like "[...] racial or ethnic origin, religious, philosophical or moral beliefs, political opinions, membership of trade unions or organizations of religious, philosophical or political character, data concerning health or sex life, as well as genetic data"43. In this sense, much of the information categorized within the public interest, with low possibility of exclusion of internet registries within the Google criteria, may violate the protection of personal data, specifically of sensitive data.

Considering that it is important to note that the categorization of possibilities of effective application of the right to be forgotten should not occur as an absolute right, but with

\footnotetext{
${ }^{39}$ BERNAL, P. Internet Privacy Rights: Rights to Protect Autonomy.

${ }^{40}$ BARLOW, John Perry. A Declaration of the Independence of Cyberspace. Disponivel em: <https://projects.eff.org/ barlow/Declaration-Final.html>. Acesso em: 23 fev. 2011.

41 BERNAL, P. Internet Privacy Rights: Rights to Protect Autonomy.

42 BERNAL, P. Internet Privacy Rights: Rights to Protect Autonomy.

${ }^{43}$ BRASIL. Anteprojeto de Lei para a Proteção de Dados Pessoais. Disponível em: <http://participacao.mj.gov.br/dadospessoais/texto-em-debate/anteprojeto-de-lei-para-a-protecao-dedados-pessoais/> . Acesso em: 28 abr. 2015.
} 
THE FUNDAMENTAL RIGHT TO PRIVACY IN BRAZIL: CONCEPTUAL INCORPORATION OF THE INTERNET PRIVACY RIGHTS IN REGULATING PERSONAL DATA PROTECTION

Vinícius Borges Fortes, SAlete Oro Boff, Fernando Galindo Ayuda

its application in balance with other rights. Thus, the right to be forgotten could always be applied, except in certain circumstances, expressly defined in standard categorical legal, and not on individual criteria defined by the agent responsible for the storage and processing of data.

So, since considered legally, limitations could be based on paternalistic grounds, for the good of the individual; for community reasons, for the good of the community; by administrative and economic reasons, including electoral and tax records; for archiving reasons, including journalistic and historical records; for reasons of freedom of expression; for reasons of national security or for the prevention of crimes $^{44}$.

Overcome the issue involving the public or private character generated by internet in cyberspace, it is essential to analyse another relevant question, directly linked to the subject treated in this section: what gives the personal data private nature of 'our' and 'personal'? In that way, it is crucial to establish a relevant difference for this research: in countries of AngloSaxon legal array, as the United States, some forms of data are considered sufficiently personal to the point that the individual hold some rights over all of these data; in the countries of Romano-Germanic legal array, like most European countries, it is considered any data that can be directly linked to an individual as a personal data ${ }^{45}$.

Thus, a possible answer would be a paradigm shift that go with the questions already evidenced, in particular to the mixed nature of an internet that shows a public space, now presents itself as private space. In a private space individuals would directly manage their own privacy settings. In a public space, they would order the protection through privacy rights. In any case, the paradigm being changed is that privacy is no longer an exception to become a general rule ${ }^{46}$. This paradigm shift is fundamental for surveillance, as suggested by Morais e $\mathrm{Neto}^{47}$, no longer has a prerequisite of acceptability, as well as the collection, processing and storage of personal data, irrespective of the end.

The paradigm shift, becoming the privacy protection as a general rule, those who wish to monitor people or collect, use, store personal data would justify, reasonably, the reasons for the surveillance, the collection, use or storage of data and personal information. If the justification is not plausible, acceptable or is not provided for within the exceptions established

\footnotetext{
${ }^{44}$ BERNAL, P. Internet Privacy Rights: Rights to Protect Autonomy.

45 BERNAL, P. Internet Privacy Rights: Rights to Protect Autonomy.

${ }^{46}$ BERNAL, P. Internet Privacy Rights: Rights to Protect Autonomy.

${ }^{47}$ MORAIS, José Luis Bolzan; NETO, Elias Jacob. A insuficiéncia do Marco Civil da Internet na protec,ão das comunicações privadas armazenadas e do fluxo de dados a partir do paradigma da surveillance.
} 
THE FUNDAMENTAL RIGHT TO PRIVACY IN BRAZIL: CONCEPTUAL INCORPORATION OF THE INTERNET PRIVACY RIGHTS IN REGULATING PERSONAL DATA PROTECTION

Vinícius Borges Fortes, SAlete Oro Boff, Fernando Galindo Ayuda

by a rule of law that recognizes positive and, effectively, the right to privacy and to protection of personal data on the internet, such data may not ever be subject to surveillance, collection, use and storage. Soon, the paradigm shift must adopt the model of privacy protection as a basic rule, mainly in the spaces formed in and through the internet ${ }^{48}$.

Thus, the right to delete personal information cannot claim strengthen censorship or rewrite history, but only provide individuals more control over their personal information, as well as encourage companies and Governments to take ownership, more efficiently, appropriate and useful data to meet particular purpose, without bringing any risk of damage or overexposure of data and personal information ${ }^{49}$.

From the four basic rights that make up the core of the concept of 'internet privacy rights', the right to delete personal data on the internet, specifically, has been sued in connection with judiciary in Brazil. In March 2013, the Brazilian Federal Justice Council (CJF) instituted the Precedent 531, during the VI Civil Journey from the Centre of Judicial Studies of the Federal Justice Council, prescribing the interpretative recommendation that "The protection of human dignity in the information society includes the right to be forgotten" 50 .

Of course, in the Brazilian context, 'the' right to be forgotten meets, there are times the goal of resocialisation of the one who breaks the law, particularly in criminal matters ${ }^{51}$. It is observed, however, the proposal CJF 531 of interpretation of the Brazilian Civil Code, so as to apply ' $a$ ' right to be forgotten the different cases and without the necessary relationship with issues involving criminal rehabilitation.

Although the concern exposed by the Federal Justice Council is legitimate, sociologically the discussion established on a global scale to reflect whether the judiciary has the legitimacy to determine, according to their 'conscience', the imposition of a 'delete button', as appropriate. As is evident, in the following cases exposed, the application of 'a' right to be forgotten is performed based on interpretation by listed and by weighting (or just thinking)

\footnotetext{
${ }^{48}$ BERNAL, P. Internet Privacy Rights: Rights to Protect Autonomy.

49 BERNAL, P. Internet Privacy Rights: Rights to Protect Autonomy.

${ }^{50}$ CONSELHO DA JUSTIÇA FEDERAL. Enunciado trata do direito ao esquecimento na sociedade da informação. Disponível em: <http://www.cjf.jus.br/cjf/noticias-do-cjf/2013/abril/enunciado-trata-dodireito-ao-esquecimento-na-sociedade-da-informacaos. Acesso em: 14 jan. 2014.

${ }^{51}$ Under article 748 of the code of criminal procedure, "The condemnation or previous convictions will not be mentioned in the record sheet of the rehabilitated, or extracted from the books of judgment certificate, except when ordered by criminal judge". In this context, the rehabilitated has the right to be forgotten exclusively with official records about his background.
} 
THE FUNDAMENTAL RIGHT TO PRIVACY IN BRAZIL: CONCEPTUAL INCORPORATION OF THE INTERNET PRIVACY RIGHTS IN REGULATING PERSONAL DATA PROTECTION

Vinícius Borges Fortes, SALETE Oro Boff, Fernando Galindo AyUda

of constitutional principles, what deserves attention and in-depth scientific analysis, especially in light of the criticism formulated by Streck ${ }^{52}$.

Before the recent application of the weighting of constitutional principles in cases involving the security of 'a right to be forgotten', it is evidenced, in the case-law of the Brazilian Superior Court of Justice (STJ), the greater elucidation of the (un)suitability of the technique as well as the (un)suitability of the interpretive process, from listed and precedents, as has occurred in the circumstances of the said building right to be forgotten in cyberspace ${ }^{53}$.

Arguably, the issues related to the internet are provided with complexity, which, in several opportunities, converted into perplexity. Presents itself, by way of example, the case involving Maria da Graça Xuxa Meneghel versus Google Brazil Internet Ltda., in which the author of the lawsuit meant the removal of all search results involving a search using the terms "xuxa paedophile" or any others that have relation with your name. In the end, the site searches was victorious, the absence of recognition, in this case, the right to be forgotten, on account of the impossibility of the search engine perform the removal of the content intended by the author of the action (it should be noted that the decision of the Superior Court of Justice established itself in information technology and not on legal grounds themselves).

It causes perplexity on the complex issue faced in special appeal No. 1.316.921-RJ (2011/0307909-6), reported by Minister Nancy Andrighi the justification to vote the Minister Massami Uyeda. As the excerpt, below, transcribed, the judge recognizes the vote of the rapporteur as the "best way at the moment", yet unfamiliar, both in the legal field and in technological orbit theme judged:

The way it is, effectively, the solution advocated by Ms. Minister Nancy Andrighi's, as s. Exa. even pointed out, the best way at the moment. But, effectively, there needs to be, also, a defence mechanism because, although the right to information is essential to this world we live in, the reality is that the honour and intimacy should be preserved.

Then, maybe, just cannot assign it, would assign this to my own knowledge of the area, not to ignore the possibility of seeking a source. [...].

\footnotetext{
${ }^{52}$ STRECK, Lenio. Segunda parte - as réplicas: neoconstitucionalismo, positivism e pós-positivismo. In: STRECK, LENIO; TRINDADE, ANDRÉ KARAM; FERRAJOLI, LUIGI (Org.). . Garantismo, hermenêutica e (neo)constitucionalismo: um debate com Luigi Ferrajoli. Porto Alegre: Livraria do Advogado, 2012b. p. 260.

${ }^{53}$ It should be noted that this research is limited to analysing this case, as regards the Brazilian jurisprudence, behold the jurisprudential analyses are not part of the scope of this investigation. This specific case is presented only by way of example of the recent trial in Brazil, directly related to the basic law to delete the personal data on the internet.
} 
THE FUNDAMENTAL RIGHT TO PRIVACY IN BRAZIL: CONCEPTUAL INCORPORATION OF THE INTERNET PRIVACY RIGHTS IN REGULATING PERSONAL DATA PROTECTION

Vinícius Borges Fortes, SALETE Oro Boff, Fernando Galindo AyUda

I want to thank this technical clarification, I confess my no knowledge, but hopefully one day come to understand this mechanism and follow the full votes of eminent Rapporteur, giving dismissed special feature ${ }^{54}$.

If there is a certainty in the vote is the transcript of that, in specified circumstances, the Brazilian judiciary's stance is far from theory of law. For this reason, it is essential to deepen the topics related to examining the application of the weighting on constitutional principles, conflicts in which focuses the root of the Brazilian judicial activism.

For Streck ${ }^{55}$ the use of weighting has construction of pan-principiologism, "a speculative bubble of the principles". For him, the lack of criteria in the use of weighting made "[...] increased fragmentation of the application of the law, being one of the reasons for the emergence of the binding and overviews of General repercussion in Brazil [...]". For these reasons, does not cause any surprise the use, in the courts of Precedent 531 by STJ and CJF, evidencing the use, in addition to weighting, interpretation by listed as grant to complete the recognition of ' $a$ ' right to be forgotten.

In fact, the posture adopted by the Brazilian judiciary, especially in the case presented, is one of the elements where you can identify the possibility of incorporation of the concept of 'internet privacy rights', especially basic rights linked to it. Furthermore, although the technical factors are relevant, is not permissible for the protection of fundamental rights is directly (and almost exclusively as Xuxa vs. Google) linked to the impossibility of fulfilment of judicial decision by technical factors. Still, the technical justification accepted by the STJ does not seem to be absolute, in order to comply with the ruling of the Spanish Court, which determined the deletion of your personal information by Google. Therefore, under the prism of information technology, it is possible the fulfilment of decisions applying the basic right to delete the personal data on the internet, although willing implicitly, as in the case of policies and regulations system of personal data protection in the European Union.

Complementary to the previous form, the fourth basic right is divided into three fronts: a right to create an online identity; a right to assert that online identity; a right to protect that online identity. According to the author, the relationship between privacy, identity and

\footnotetext{
${ }^{54}$ BRASIL. Superior Tribunal de Justiça. Acórdão em Recurso Especial n. ${ }^{\circ} 1.316 .921$ - RJ (2011/0307909-6). Relatora Ministra Nancy Andrighi. Disponível em:

<https://ww2.stj.jus.br/processo/revista/documento/mediado/?componente=ITA\&sequencial=1161904\&n um_registro $=201103079096 \&$ data $=20120629 \&$ formato=PDF $>$.

${ }_{55}$ STRECK, L L. O que é isto - decido conforme a minha consciência? Porto Alegre: Livraria do Advogado, 2012. p. 12
} 
THE FUNDAMENTAL RIGHT TO PRIVACY IN BRAZIL: CONCEPTUAL INCORPORATION OF THE INTERNET PRIVACY RIGHTS IN REGULATING PERSONAL DATA PROTECTION

Vinícius Borges Fortes, SAlete Oro Boff, Fernando Galindo Ayuda

autonomy is complex, subtle and always evolving, particularly by the fact the relations established on the internet require, in one way or another, an identity to be used, either in social networks, access to Bank online services, either as a username to play online ${ }^{56}$.

How the identity reveals about the 'real person' behind the 'virtual' individual is a matter assigned exclusively to the law of that individual in determining such information 'real'. In some places and in some situations, the connection between the 'real' identities and 'virtual' need to show clear and explicit, but these situations are much more rare than in this systematic operation businesses generally suggest. In other words, the internet which adopts as standard rule a policy of 'real names' is the same in which the privacy and autonomy of people are needlessly compromised. Thus, a change of paradigm, relevant in view of author, resides precisely in reversing the rule, being the requirement of real identities the exception ${ }^{57}$.

The amount of information that an internet user needs to reveal to access a service or system should, in general, be minimized. The idea of disclosure minimized - and that includes the disclosure of online identity as a set of personal information - with the design data minimisation, which configures a key aspect for a data protection regime and a crucial part for the privacy of the data on the internet. Therefore, privacy on the internet is primarily related to the protection of identities, while the autonomy deals with the control of these identities by their holders.

\section{CONCLUSIONS}

This research reached the objective to observe and identify internet privacy rights in legal norms compared, proposing the explicit insertion and expresses the concept of internet privacy rights as one of the elements to ensure greater magnitude in the effectiveness of the fundamental right to privacy in particular, in the process of regulating the protection of personal data on the internet.

Considering that objective, it is possible to say that the conceptual vagueness in legal provisions, with regard to the context of the internet, especially in the protection of privacy and the inviolability of personal data is a relevant element to support the confirmation of the hypothesis that internet privacy rights need to be incorporated conceptually, explicitly and

${ }^{56}$ BERNAL, P. Internet Privacy Rights: Rights to Protect Autonomy.
57 BERNAL, P. Internet Privacy Rights: Rights to Protect Autonomy. 
THE FUNDAMENTAL RIGHT TO PRIVACY IN BRAZIL: CONCEPTUAL INCORPORATION OF THE INTERNET PRIVACY RIGHTS IN REGULATING PERSONAL DATA PROTECTION

Vinícius Borges Fortes, SAlete Oro Boff, Fernando Galindo Ayuda

expressly, in internet-related legal rules in Brazil, in order to ensure full effectiveness to the fundamental right to privacy mainly by welcoming private life protection, of intimacy, of the image, honour and the basic rights, linked to basic rights to roam the internet with privacy, monitor those who monitor us, delete personal information and to protect your online identity.

From these partial conclusions, it is considered that:

1) the conceptual proposition of internet privacy rights, defended in this research, cannot be limited to mere conceptual recognition. It is necessary to seek the incorporation of internet privacy rights, including explicitly and expressly those rights in the process of building regulations in Brazil, related to the topic as a means to greater extent the effectiveness of the fundamental right to privacy, in this case in the context of the internet;

2) conceive privacy on the internet as a fundamental right, in a broad sense, including private life protection, of intimacy, of the image, honour and the basic rights linked to the concept of internet privacy rights, means that, in contemporary times, the right to roam the internet with privacy, the right to monitor those who monitor us, the right to delete personal data and the right to protect the identity should be protected online, explicitly and expressly, as one of the pillars of ensuring the effectiveness of the fundamental right to privacy in broad sense.

3) the expressed reception of internet privacy rights by legal norms, which address and related subjects will still in Brazil, allows the recomposition of the core of the fundamental right to privacy that, according to the theories presented in this research, incorporating only the protection of private life, honour, intimacy and image. In other words, it should be noted that the fundamental right to privacy should also integrate its nuclear rights structure of privacy on the internet, so that, in Brazil, the civil legislation of Internet and editing a personal data protection act expressly entitled to behold, roaming the internet with privacy; the right to monitor those who monitor us; the right to delete your personal data; the right to identity protection online;

4) Thus, the fundamental right to privacy on the internet is wider dimension and, above all, current and contextualized with the information society, allowing for better fitting of the right on the new modes of social interaction that the internet presents repeatedly, as well as makes it feasible facing legal problems arising from a networked society or of a 'surveillance State'.

Settled, therefore, a theoretical-conceptual link to answer the problem of research: internet privacy rights must be expressed and explicit, to ensure greater amplitude on efficiency 
THE FUNDAMENTAL RIGHT TO PRIVACY IN BRAZIL: CONCEPTUAL INCORPORATION OF THE INTERNET PRIVACY RIGHTS IN REGULATING PERSONAL DATA PROTECTION

Vinícius Borges Fortes, SAlete Oro Boff, Fernando Galindo Ayuda

of legal norms that protect the Brazilian straight crucial to privacy in the context of the internet? Thus, the research did the overall objective of proposing the conceptual incorporation of internet privacy rights, explicitly and expressly, as one of the pillars to ensure greater magnitude in the effectiveness of the fundamental right to privacy, in particular in the process of creating regulations in Brazil, related to the protection of personal data on the internet, confirming the hypothesis that internet privacy rights must be explicit and in internet-related legal rules in Brazil to ensure greater effectiveness of the fundamental right to privacy.

Based $^{58}$ on Orwell (1983) a piece of the book that starts this paper, "[...] to the future or to the past, to a time when thought is free [...]", may, on the internet or outside of it, men be equal, and that they do not live alone - to a time when truth exists and that each subject has the possibility to decide which piece of their information is private and what is public, and that what is done can be undone: the era of private roaming on the internet, the age of accountability of those who monitor us, the age of the right to delete personal data, the age of online identity protection, the age of internet privacy rights - greetings!

\section{REFERENCES}

ASSEMBLEIA GERAL DAS NAÇÕES UNIDAS. Resolution adopted by the General Assembly on 18 December 2014 - 69/166. The right to privacy in the digital age. New York: [s.n.].

BARBOSA, A. F. Pesquisa sobre o uso das Tecnologias de Informação e Comunicação no Brasil TIC Domicílios e Empresas 2013. São Paulo: Comitê Gestor da Internet no Brasil, 2014.

BARLOW, J. P. A Declaration of the Independence of Cyberspace. Disponivel em:

<https://projects.eff.org/ barlow/Declaration-Final.html>. Acesso em: 23 fev. 2011.

BERNAL, P. Internet Privacy Rights: Rights to Protect Autonomy. Cambridge (UK): Cambridge University Press, 2014.

BRASIL. Exposição de motivos ao projeto de lei . $^{\circ} 2.126 / 2011$. Disponível em:

<http://www.planalto.gov.br/ccivil_03/Projetos/ExpMotiv/EMI/2011/86-MJ MP MCT MC.htm>. Acesso em: 24 dez. 2012.

\footnotetext{
${ }^{58}$ To the future or to the past, to a time when thought is free, when men are different from one another and do not live alone - to a time when truth exists and what is done cannot be undone: From the age of uniformity, from the age of solitude, from the age of Big Brother, from the age of doublethink greetings! (ORWELL, 1983).
} 


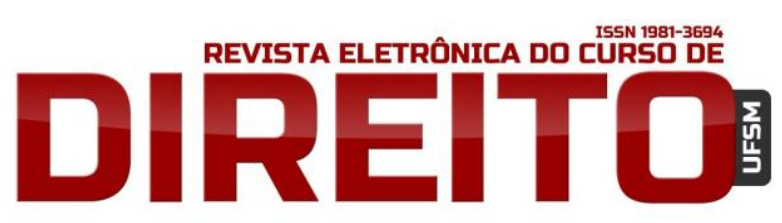

THE FUNDAMENTAL RIGHT TO PRIVACY IN BRAZIL: CONCEPTUAL INCORPORATION OF THE INTERNET PRIVACY RIGHTS IN REGULATING PERSONAL DATA PROTECTION

Vinícius Borges Fortes, SALETE Oro Boff, Fernando GaLindo AyUda

BRASIL. Brasil quer modelo "multistakeholder" para gestão democrática da Internet.

Disponível em: <http://www.brasil.gov.br/governo/2013/10/brasil-quer-modelo-

201 cmultistakeholder201d-para-gestao-democratica-da-internet>. Acesso em: 14 mar. $2015 a$.

BRASIL. Superior Tribunal de Justiça. Acórdão em Recurso Especial n. ${ }^{\circ}$ 1.316.921 - RJ (2011/0307909-6). Relatora Ministra Nancy Andrighi. Disponível em:

<https://ww2.stj.jus.br/processo/revista/documento/mediado/?componente=ITA\&sequencial=1 161904\&num_registro=201103079096\&data=20120629\&formato=PDF $>$.

BRASIL. Lei n. $^{\circ}$ 12.965, de 23 de abril de 2014. Disponível em:

<http://www.planalto.gov.br/ccivil_03/_ato2011-2014/2014/lei/l12965.htm>. Acesso em: 21 abr. 2015.

BRASIL. Anteprojeto de Lei para a Proteção de Dados Pessoais. Disponível em: <http://participacao.mj.gov.br/dadospessoais/texto-em-debate/anteprojeto-de-lei-para-aprotecao-de-dados-pessoais/>. Acesso em: 28 abr. 2015.

CONSELHO DA JUSTIÇA FEDERAL. Enunciado trata do direito ao esquecimento na sociedade da informação. Disponível em: <http://www.cjf.jus.br/cjf/noticias-do-cjf/2013/abril/enunciadotrata-do-direito-ao-esquecimento-na-sociedade-da-informacao>. Acesso em: 14 jan. 2014.

CONSELHO DE DIREITOS HUMANOS DAS NAÇÕES UNIDAS. Criação da Relatoria Especial sobre "O Direito à Privacidade na Era Digital". Disponível em:

<http://www.itamaraty.gov.br/index.php?option=com_content\&view=article\&id=8460: criacaoda-relatoria-especial-sobre-o-direito-a-privacidade-na-era-

digital\&catid=42\&ltemid=280\&lang=pt-BR>. Acesso em: 31 mar. 2015.

GOOGLE. Report of The Advisory Council to Google on the Right to be Forgotten Members of the Council. San Francisco, EUA: [s.n.]. Disponível em:

<https://drive.google.com/file/d/0B1UgZshetMd4cEI3SjlvVOhNbDA/view>.

GREENWALD, G.; KAZ, R.; CASADO, J. EUA espionaram milhões de e-mails e ligações de brasileiros - Jornal O Globo. O Globo, jul. 2013.

JÄÄSKINEN, N. Conclusões do advogado-geral apresentadas em 25 de junho de 2013 Processo C-131/12 - Google Spain SL, Google Inc. vs. Agencia Española de Protección de Datos, Mario Costeja González. [s.l: s.n.].

JÚNIOR, A. R.; NETO, A. R. Direito ao Esquecimento e o Superinformacionismo - Apontamentos no Direito Brasileiro dentro do Contexto de Sociedade da Informação. Revista do Instituto do Direito Brasileiro, v. 1, n. 2012, p. 419-434, 2012.

MORAIS, J. L. B.; NETO, E. J. A insuficiencia do Marco Civil da Internet na protecão das comunicaç,óes privadas armazenadas e do fluxo de dados a partir do paradigma da surveillance. In: LEITE, G.; LEMOS, R. (Eds.). . Marco Civil da Internet. São Paulo: Atlas, 2014. p. 417-439.

ORWELL, G. 1984. New York: Houghton Mifflin Harcourt, 1983. 
STRECK, L. Segunda parte - as réplicas: neoconstitucionalismo, positivism e pós-positivismo. In: STRECK, L.; TRINDADE, A. K.; FERRAJOLI, L. (Eds.). . Garantismo, hermenêutica e (neo)constitucionalismo: um debate com Luigi Ferrajoli. Porto Alegre: Livraria do Advogado, 2012a. p. 260.

STRECK, L. L. O que é isto - decido conforme a minha consciência? Porto Alegre: Livraria do Advogado, 2012b.

Tesco stocks up on inside knowledge of shoppers' lives. The Guardian, 20 set. 2005.

TIBKEN, S. Google' s Schmidt : The Internet needs a delete button. Disponível em: <http://www.cnet.com/news/googles-schmidt-the-internet-needs-a-delete-button/>. Acesso em: 23 ago. 2013.

VARELLA, M. D. Internacionalização do direito: direito internacional, globalização e complexidade. Brasilia: UniCEUB, 2013.

WARREN, S. D.; BRANDEIS, L. D. The Right to Privacy. Harvard Law Review Vo - 4, n. 5, p. 193, 1890.

Recebido em: 30.09.2015 / Revisões requeridas em: 29.05.2016 / Aprovado em: 20.06.2016 